\title{
ASSESSMENT OF SELECTED NUTRITIONAL BEHAVIOURS AMONG COLLEGE ADOLESCENTS FROM POMERANIA PROVINCE
}

\author{
Joanna Bartkowicz ${ }^{1}$, Katarzyna Mironiuk ${ }^{2}$ \\ ${ }^{1}$ Faculty of Physiotherapy and Health Sciences, Gdansk Management College, \\ Pelplińska 7, 80-335 Gdańsk, Poland \\ ${ }^{2}$ Gdynia Maritime University, Faculty of Enterpreneurship and Quality Science, Gdynia, Poland
}

\begin{abstract}
Background. Adequate nutrition is one of the most important environmental factor that determines the development of children and adolescents. Childhood, as well as puberty significantly take part in forming proper nutritional attitudes and behaviours. Objectives. Assessment of selected nutritional behaviors among college adolescents from Pomerania Province. Subjects were students of high schools, trade schools and technical institutes.

Material and methods. In the study 198 students participated - 121 girls and 77 boys. A study was conducted during school year 2012/2013. Nutritional behavior was assessed due to an anonymous questionnaire that concerned nutritional self-assessment of adolescents, their interests in healthy dietary patterns, amount and type of daily consumed foods, time of consumption of last meal of the day, snacking between main meals; frequency together with a quality of the snacks, and sources of dietary knowledge acquisition.

Results. Data analysis showed that boys ate dinner and supper statistically significantly more frequently than girls. Gender also defined consumption of products from different food groups. Boys statistically significantly more often were choosing white bread, dumplings, pasta, milk, red meat, poultry and eggs. The amount of underweight girls was three times higher than underweight boys. Snacking was observed in $99.0 \%$ of the study group. Diet regimens were conducted statistically more often by girls $(37.5 \%)$ than boys $(6.3 \%)$.

Conclusions. It has been shown that there are a number of abnormal nutritional behaviors in the study group. This indicates the need for their correction through the education of both young people, but also parents and legal guardians. It is recommended that workshops, youth training by nutritionists in the field of proper nutrition and eating behavior.
\end{abstract}

Key words: adolescents, nutritional attitudes, gender, nutrition knowledge, snacking.

\section{STRESZCZENIE}

Wprowadzenie. Prawidłowe żywienie jest jednym z najważniejszych czynników środowiskowych, które wpływają na rozwój dzieci i młodzieży. Okres dzieciństwa i dojrzewania ma szczególne znaczenie w kształtowaniu właściwych nawyków i zachowań żywieniowych.

Cel badań. Celem badania była ocena wybranych zachowań żywieniowych młodzieży szkół średnich (ponadgimnazjalnych) w województwie pomorskim. Badani uczęszczali do liceów, techników i szkół zawodowych gastronomicznych.

Materiał i metody. W badaniu wzięło udział 198 uczniów szkół średnich, w tym 121 dziewcząt i 77 chłopców. Badanie przeprowadzono w roku szkolnym 2012/2013. Ocenę zachowań oparto na anonimowym kwestionariuszu ankiety, zawierającym pytania dotyczące: regularności spożywanych posiłków, pojadania między posiłkami, jakości i częstości spożywanych produktów spożywczych, pory ostatniego posiłku, samooceny sposobu odżywiania i posiadanej wiedzy żywieniowej badanych, źródeł zdobywania wiedzy żywieniowej przez młodzież.

Wyniki. Analiza danych wykazała, iż chłopcy spożywali obiady i kolacje istotnie częściej niż dziewczęta. Płeć również różnicowała spożycie wybranych produktów spożywczych. Chłopcy istotnie częściej spożywali biały chleb, kluski, makarony, mleko, mięso wieprzowe i wołowe, drób oraz jaja. Dziewczynek z niedowagą było trzykrotnie więcej niż chłopców. Pojadanie między posiłkami stwierdzono u 99.0\% badanych. Diety stosowały statystycznie częściej dziewczęta (37.5\%) niż chłopcy (6.3\%).

Wnioski. Wykazano, że w badanej grupie występuje szereg nieprawidłowych zachowań żywieniowych. Wskazuje to, na potrzebę ich korekty poprzez edukację zarówno młodzieży, ale także rodziców, opiekunów. Wskazane są warsztaty, szkolenia młodzieży przez dietetyków z zakresu prawidłowego żywienia i zachowań żywieniowych.

Słowa kluczowe: młodzież, zachowania żywieniowe, płeć, wiedza żywieniowa, pojadanie

Corresponding author:Joanna Bartkowicz, Gdansk Management College, Faculty of Physiotherapy and Health Sciences, 80-335 Gdańsk, Pelplińska str. 7, Poland, e-mail: viobart@op.pl, tel. +48 600697499 


\section{INTRODUCTION}

Proper nutrition is one of the most important environmental factor determining development of adolescents which results in maintaining a good health in their adulthood. It mainly concentrates on recommended intake of calories together with essential nutrients. Social group that is significantly endangered by the exposition to the negative results of incorrect eating habits are kids and adolescents [14]. Long-drawn malnutrition leads to energy and protein deficiency, which caused in a young age might result in an inhibition of physical and intellectual development, cognitive functions impairment as well as disorders in immune system. It also might have its consequences in social and psychological aspects. Moreover, excess weight has a negative impact on growth and health not only in the childhood, but also has a crucial effect on healthiness in later life, increasing risk of non-communicable chronic diseases or different kinds of disabilities [10]. A large number of national research focused on assessment of nutrition in this population showed numerous nutritional fallacies. They refer both to type and texture of consumed foods, as well as to snacking. Qualitatively and quantitatively poorly composed meals together with an inadequate time of consumption are blamed for dietary insufficiencies, leading to deficiency of macronutrients, minerals and vitamins, even if the energy intake is excessive $[7,11$, 26] According to healthy nutrition guide [14] the energy should be mainly acquired from whole grain products. Milk and dairy products should become an essential element of everyday diet, together with vegetables and fruits. An adequate intake of meat, eggs and fish is also important. All those are meant to ensure and preserve the proper amount of proteins, vitamins and minerals necessary to maintain growth process in adolescents' bodies. Apart from products that should be contained in children's everyday diet there are products such as sugar and sweets that may occur from time to time, but their consumption should be restrained and controlled.

The aim of a study was to demonstrate impact of gender on selected components of basic feeding nutritional behaviors and attitudes of adolescents from high school.

\section{MATERIALS AND METHODS}

A study was conducted with a survey method among 198 college students (121 girls and 77 boys) from high schools, trade schools and technical institutes based in rural and urban environment. A study was conducted during school year 2012/2013. The study group age was 15-20 years old. The used method was a diagnostic survey based on an anonymous questionnaire. It contained questions concerning: nutritional self-assessment of adolescents; their interests in healthy dietary patterns; amount and type of daily consumed foods; time of consumption of a last meal of a day; snacking between main meals; frequency together with a quality of the snacks, and sources of dietary knowledge acquisition. They were also asked about any diet regimen proceedings. The degree of liking the range of selected products was defined by 5-point hedonic scale, and the 4-point scale was used to define intake frequency. Products to assess represented by typical foods from all six basic food groups. Nutritional status assessment was conducted by use of BMI (Body Mass Index) centile charts for both sex and age: for underweight BMI below $5^{\text {th }}$ centile, for normal weight between $5^{\text {th }}$ and $85^{\text {th }}$ centile, for overweight more than $85^{\text {th }}$ but less than $95^{\text {th }}$ centile, and for obesity equal or more than $95^{\text {th }}$ centile [16]. Obtained results were confronted with nutritional guidelines for children and adolescents provided by National Food and Nutrition Institute in Poland. All statistical analysis were performed using the software Statistica PL 10 provided by StatSoft company. To find statistically significant differences was used $\mathrm{Chi}^{2}$ test $\left(\chi^{2}\right)$ with the value of a statistically significant difference $\mathrm{p}<0.05$.

\section{RESULT AND DISCUSSION}

The characteristic of a study group was shown in a Table 1. Accordingly to BMI, $78.8 \%$ of students had normal weight, $10.1 \%$ was overweight, $7.1 \%$ was underweight and $4.0 \%$ was obese. The underweight adolescents group consisted 3 times more girls than boys (9.9\% vs $2.6 \%)$. Food preferences of a sample group analyzed by degree of liking and intake frequency of all food groups (according to the WHO recommendations) was collated in Table 2. Not all the foods liked by adolescents had their reflection in the frequency of consumption. It was claimed that boys are drinking (statistically significant) more milk and eating more eggs, red meats, poultry and its products comparing to girls. Most frequently consumed foods by girls were fruits, vegetables and white bread, where boys were choosing white bread, vegetables and meat products. Bread made of processed (white) flour is preferred more than whole grain flour products, also the consumption of sweets is high in both groups. Ingestion of fish, milk and dairy products as well as vegetables and fruits was too low. Comforting was the fact of little intake of cola-like drinks, fast food and ice-cream despite that they were defined with a high degree of liking. Daily vegetables consumption was declared by $44.6 \%$ girls and $41.6 \%$ boys, even though both groups defined a degree of liking them at range "like" - "like a lot". Fruit intake was higher in a group of girls (47.9\%) than boys (35.1\%) but still it was generally low and did not meet the dietary recommendations. Rare chips consumption ("less than once a week") was claimed by $62.0 \%$ girls and that was much more comparing to boys (48.1\%). Considering intake and degree of liking sweets; girls and boys alike showed a restraint in consumption. 
Table 1. Characteristics of the study population

\begin{tabular}{|c|c|c|}
\hline \multirow[t]{2}{*}{ Parameters } & $\begin{array}{c}\text { Female } \\
\mathrm{n}=121(61.1 \%)\end{array}$ & $\begin{array}{c}\text { Male } \\
\mathrm{n}=77(38.9 \%)\end{array}$ \\
\hline & \multicolumn{2}{|c|}{$\mathrm{X} \pm \mathrm{SD}$} \\
\hline Age [years] & $17.4 \pm 0.8$ & $17.6 \pm 1.1$ \\
\hline Height $[\mathrm{cm}]$ & $168.2 \pm 6.0$ & $180.0 \pm 6.0$ \\
\hline Body mass [kg] & $57.7 \pm 9.0$ & $74.1 \pm 10.7$ \\
\hline \multicolumn{3}{|c|}{ Evaluation of nutrition status among examined students on the basis of BMI index } \\
\hline Obesity & $4 / 3.3 \%$ & $4 / 5.2$ \\
\hline Overweight & $11 / 9.1 \%$ & 9/ 11.7 \\
\hline Normal & $94 / 77.7 \%$ & $62 / 80.5 \%$ \\
\hline Underweight & $12 / 9.9 \%$ & $2 / 2.6 \%$ \\
\hline
\end{tabular}

$\mathrm{X}$ - mean, SD Standard Deviation

Table 2. The average intake frequency and degree of liking of various food products [mean $\pm \mathrm{SD}]$

\begin{tabular}{|c|c|c|c|c|c|c|}
\hline \multirow{3}{*}{ Product } & \multirow{2}{*}{\multicolumn{2}{|c|}{$\begin{array}{c}\text { Intake frequency } \\
\mathrm{X}_{s \mathrm{~s}} \pm \mathrm{SD} \\
\text { Sex }\end{array}$}} & \multirow{3}{*}{$\begin{array}{l}\text { Statistical } \\
\text { significance } \\
\text { (p-value) }\end{array}$} & \multirow{2}{*}{\multicolumn{2}{|c|}{$\begin{array}{c}\text { Degree of liking } \\
\mathrm{X}_{\mathrm{sr}} \pm \mathrm{SD} \\
\mathrm{Sex}\end{array}$}} & \multirow{3}{*}{$\begin{array}{c}\text { Statistical } \\
\text { significance } \\
\text { (p-value) }\end{array}$} \\
\hline & & & & & & \\
\hline & Female & Male & & Female & Male & \\
\hline \multicolumn{7}{|c|}{ Group 1} \\
\hline White bread & $3.05 \pm 1.07$ & $3.47 \pm 0.88$ & $\mathrm{SS}(\mathrm{p}=0.016)^{* *}$ & $3.70 \pm 0.95$ & $3.79 \pm 0.99$ & $\mathrm{NS}^{*}$ \\
\hline Whole grain bread & $2.78 \pm 1.10$ & $2.36 \pm 1.07$ & NS & $4.01 \pm 1.01$ & $3.64 \pm 1.06$ & $\mathrm{SS}(\mathrm{p}=0.014)$ \\
\hline Grains, rice & $2.14 \pm 0.99$ & $2.38 \pm 0.97$ & NS & $3.71 \pm 0.95$ & $3.78 \pm 0.94$ & $\mathrm{SS}(\mathrm{p}=0.250)$ \\
\hline Dumplings, pasta & $1.93 \pm 0.87$ & $2.43 \pm 0.88$ & $\mathrm{SS} \mathrm{p}=0.002$ & $3.79 \pm 0.99$ & $3.91 \pm 0.86$ & NS \\
\hline \multicolumn{7}{|c|}{ Group 2} \\
\hline Vegetables & $3.28 \pm 0.81$ & $3.27 \pm 0.72$ & NS & $4.03 \pm 0.92$ & $3.69 \pm 0.96$ & NS \\
\hline Fruits & $3.32 \pm 0.79$ & $3.17 \pm 0.78$ & NS & $4.63 \pm 0.75$ & $4.40 \pm 0.83$ & NS \\
\hline \multicolumn{7}{|c|}{ Group 3} \\
\hline Milk & $2.57 \pm 1.15$ & $3.11 \pm 1.01$ & $\mathrm{SS}(\mathrm{p}=0.003)$ & $3.60 \pm 1.14$ & $3.94 \pm 1,03$ & NS \\
\hline Yoghurts & $2.63 \pm 1.05$ & $2.64 \pm 0.97$ & NS & $4.22 \pm 1.01$ & $4.16 \pm 0.76$ & NS \\
\hline Cheese & $2.69 \pm 1.03$ & $3.01 \pm 1.04$ & $\mathrm{NS}$ & $3.80 \pm 1.04$ & $3.83 \pm 0.98$ & NS \\
\hline White cheese & $1.88 \pm 1.04$ & $1.92 \pm 1.00$ & NS & $3.40 \pm$ & $3.44 \pm 1.18$ & $\mathrm{SS}(\mathrm{p}=0.018)$ \\
\hline \multicolumn{7}{|c|}{ Group 4} \\
\hline Portk & $1.93 \pm 0.92$ & $2.52 \pm 0.82$ & $\mathrm{SS}(\mathrm{p}=0.000)$ & $3.20 \pm 1.08$ & $3.83 \pm 1.07$ & NS \\
\hline Beef & $1.71 \pm 0.87$ & $2.21 \pm 0.94$ & $\mathrm{SS}(\mathrm{p}=0.002)$ & $3.24 \pm 1.08$ & $3.86 \pm 1.10$ & NS \\
\hline Poultry & $2.64 \pm 0.83$ & $2.96 \pm 0.68$ & $\mathrm{SS}(\mathrm{p}=0.046)$ & $4.10 \pm 0.78$ & $4.27 \pm 0.87$ & NS \\
\hline Meat products & $2.87 \pm 1.03$ & $3.26 \pm 0.87$ & NS & $3.69 \pm 1.02$ & $3.96 \pm 0.92$ & NS \\
\hline Fish & $1.66 \pm 0.77$ & $1.87 \pm 0.80$ & $\mathrm{NS}$ & $3.45 \pm 1.25$ & $3.66 \pm 1.17$ & NS \\
\hline Eggs & $1.98 \pm 0.89$ & $2.56 \pm 0.87$ & $\mathrm{SS}(\mathrm{p}=0.000)$ & $3.69 \pm 0.91$ & $3.79 \pm 0.97$ & NS \\
\hline \multicolumn{7}{|c|}{ Group 5} \\
\hline Potato crisps & $1.59 \pm 0.86$ & $1.83 \pm 0.98$ & NS & $3.55 \pm 1.00$ & $3.64 \pm 1.07$ & NS \\
\hline $\begin{array}{l}\text { Sweets/chocolate /bars, } \\
\text { waffles }\end{array}$ & $2.59 \pm 1.01$ & $2.55 \pm 0.99$ & NS & $4.14 \pm 0.92$ & $4.03 \pm 0.99$ & NS \\
\hline Cookies & $2.28 \pm 0.99$ & $2.25 \pm 0.93$ & NS & $4.09 \pm 0.85$ & $3.96 \pm 0.87$ & NS \\
\hline $\begin{array}{l}\text { Fast-food/Hamburgers, } \\
\text { hot-dogs/ }\end{array}$ & $1.18 \pm 0.50$ & $1.36 \pm 0.76$ & NS & $3.54 \pm 1.24$ & $3.75 \pm 1.16$ & NS \\
\hline Sodas, Cola-like drinks & $1.86 \pm 1.07$ & $2.33 \pm 1.12$ & NS & $3.56 \pm 1.32$ & $3.74 \pm 1.12$ & $\mathrm{SS}(\mathrm{p}=0.010)$ \\
\hline Ice-cream & $1.26 \pm 0.60$ & $1.42 \pm 0.71$ & NS & $4.16 \pm 0.92$ & $4.05 \pm 1.00$ & NS \\
\hline
\end{tabular}

Scale of consumption frequency: „every day or several times a week” score $=4$, , few times a week” score $=3$, ,once a week” score $=2$, „lees than once a week" score=1. Scale of liking: „dislike very much” score=1, „not like” score=2, ,indifferent” score=3, „I like” score $=4$, "I like a lot" score $=5$.

${ }^{*} \mathrm{NS}$ - statistically non-significant, ${ }^{* *} \mathrm{SS}$ - statistically significant (p-value in $C h i^{2}$ test) 
Gajda and Jeżewska-Zychowicz obtained results where girls had statistically significantly more often than boys declared sodas and sweets intake, where in a meantime more boys affirmed consumption of hamburgers [9]. An important issue in adolescents nutrition is the quantity and frequency of consumed meals. Youngsters should be provided with at least 4 to 5 meals a day, maintaining regular fasting hours to less than 4 hours between the treats. Attention should be also paid to proper energy distribution among all the meals. Due to that reason, at least one meal of a day should be consumed during the school time [5].

A study had shown that dinner was consumed with the highest frequency by adolescents, and it was statistically more frequent among boys. Everyday breakfast was consumed by $60.3 \%$ girls and $55.8 \%$ (statistically no-significant difference). Three times more girls $(17.4 \%)$ than boys $(5.2 \%)$ were not consuming supper, which might be associated with girls' pursuit of a skinny figure (Table 3). Irregular meals consumption phenomenon, especially skipping breakfast, had found its acknowledgements in other studies [7, 8, 23, 27]. Wołowski and Jankowska presented that the meal that was consumed by teenagers everyday was dinner $(97.4 \%)$, on contrary to afternoon snacks, which turned out to be the least likely consumed meal of a day [28]. It was also confirmed by Sochacka-Tatara and Styputa claiming that afternoon snacks are the most omitted and that $10.3 \%$ of their sample group did not eat proper breakfast in the morning [21].

In the HELENA studies took part 3000 adolescents between the ages of 13-17 years old from 10 European cities: Athens (Greece), Dortmund (Germany), Ghent (Belgium), Heraklion (Greece), Lille (France), Pecs (Hungary), Rome (Italy), Vienna (Austria), Stockholm (Sweden), and Saragossa (Spain). [12]. It was also found out that boys were regularly consuming breakfasts more often than girls, however, they were not consequent in that. One of the reasons for such differences in omitting those meals was avoiding them on purpose, and the aim was to control body mass by girls. Researchers did not realize one particular factor that also has an effect, which is age.

It was also noted by Stankiewicz at al. that girls did not eat breakfast more frequently than boys (respectively $13.7 \%$ vs. $10.2 \%$ ). The most popular reason given by female respondents were dietary restrictions caused by lack of satisfaction from their body image [22]. Pederson at al. also observed occurrence of irregular meal consumption combined with low vegetable and fruit intake among Danish adolescents as one of the study results from HBSC (Health Behavior in School-Aged Children Study) [18]. Youngsters from Finland and Greece in a high proportion decided to not eat breakfast too. Regular consumption was noted in $74.7 \%$ of Finnish boys, $48.8 \%$ of Greek boys, given female group consumption outcome on a respective level $61.6 \%$ and $44.1 \%$ [25]. Students from Gourgan (Iran) also had problems with eating meals regularly. Only $40.3 \%$ had breakfast every day, daily vegetable consumption was observed in $51.9 \%$ of study group and $10 \%$ consumed fruits only once or twice a week [2]. Almost half on a study group from Teheran (Iran) was omitting breakfast and $8.3 \%$ was skipping dinner [1]. Similar outcomes had researchers from Hong Kong. Among studied youngsters only $46 \%$ ate breakfast every day [17].

It is recommended to consume the last meal of a day no later than 2-3 hours before going to sleep. To this dietary direction students adjusted in a various manner. It was more important in a better way to girls than to boys (significant statistic difference $\mathrm{p}=0.017$ ), on the other hand to $13.2 \%$ of them "it doesn't matter" (Figure 1). Those girls are the part of the sample group that self-assessed their nutrition as "good" (5.0\%), "neither good or bad" (5.8\%) and "bad" (2.4\%). Boys showed much less strict approach towards dietary recommendations. Those who did not care for the time of meal consumption, self-assessed their nutrition as "neither good or bad" (14.3\%) and "good" (3.9\%). Supper, as a last meal before going to sleep, was omitted by three times more girls $(17.4 \%)$ than boys (5.2\%) (Table 3 ).

Snacking might be a positive thing, healthy even on the condition that it will be followed with foods recommended in a healthy diet for adolescents such as vegetables, fruits, fruit based desserts, natural milk drinks (yoghurts, buttermilk, kefir), natural cereals, dried fruits, nuts and seeds (pumpkin or sunflower). Whereas snacks like sweets, salted pretzels or crackers, fries and chips, and fast foods should be strictly avoided [13].

Snacking applied to $99.0 \%$ respondents. Barely $1.0 \%$ of a sample group declared non-snacking between meals, and those were girls only. The statistically significant differences in terms of snacking occurrence between both groups were not noted $(\mathrm{p}=0.348)$. Girls in the study declared "often" snacking- estimated at $33.9 \%$ where in case of boys it was $44.2 \%$. The "from time to time" frequency was noted among $47.1 \%$ of girls and $39.0 \%$ boys. Similar percentage of boys (17.4\%) and girls $(16.9 \%)$ was snacking "rarely".

Study of Babicz-Zielinska at al. also showed habit of snacking in $82 \%$ of girls that were representing the sample group [3]. Gacek conducted a study among 14-16 years old students and observed that snacking applied to $70 \%$ girls and $72 \%$ boys [8]. Szerbiński at al. showed that $80 \%$ of boys and about $70 \%$ of girls from Sokólski region was also snacking between meals [24]. 
Table 3. Regularity of daily meals consumption in correlation with gender

\begin{tabular}{|c|c|c|c|c|}
\hline \multirow[b]{2}{*}{ Regularity of consuption } & \multirow[b]{2}{*}{ All } & \multicolumn{2}{|c|}{ Sex } & \multirow{2}{*}{$\begin{array}{c}\text { Statistical } \\
\text { significance } \\
\text { (p-value) }\end{array}$} \\
\hline & & Female & Male & \\
\hline \multicolumn{4}{|c|}{ I breakfast } & $\mathrm{NS}^{*}$ \\
\hline Everyday & 58.6 & 60.3 & 55.8 & \\
\hline A couple times a week & 16.6 & 14.9 & 19.5 & \\
\hline Rarely or never & 24.8 & 24.8 & 24.7 & \\
\hline \multicolumn{4}{|c|}{ II breakfast } & NS \\
\hline Everyday & 49.0 & 52.9 & 42.9 & \\
\hline A couple times a week & 24.8 & 20.6 & 31.2 & \\
\hline Rarely or never & 26.2 & 26.5 & 26.9 & \\
\hline \multicolumn{4}{|c|}{ Dinner } & $\mathrm{SS}\left(\mathrm{p}=0.033^{* *}\right)$ \\
\hline Everyday & 72.3 & 67.8 & 84.4 & \\
\hline A couple times a week & 21.7 & 27.2 & 13.0 & \\
\hline Rarely or never & 4.0 & 5.0 & 2.6 & \\
\hline \multicolumn{4}{|c|}{ Afternoon snack } & NS \\
\hline Everyday & 3.8 & 32.3 & 3.8 & \\
\hline A couple times a week & 34.9 & 35.5 & 33.8 & \\
\hline Rarely or never & 32.3 & 32.2 & 32.4 & \\
\hline \multicolumn{4}{|c|}{ Supper } & $\mathrm{SS}(\mathrm{p}=0.028)$ \\
\hline Everyday & 67.7 & 62.0 & 76.6 & \\
\hline A couple times a week & 19.7 & 20.7 & 18.2 & \\
\hline Rarely or never & 12.6 & 17.3 & 5.2 & \\
\hline
\end{tabular}

${ }^{*} \mathrm{NS}$ - statistically non-significant, ${ }^{* *} \mathrm{SS}$ statistically significant (p-value in $C h i^{2}$ test)

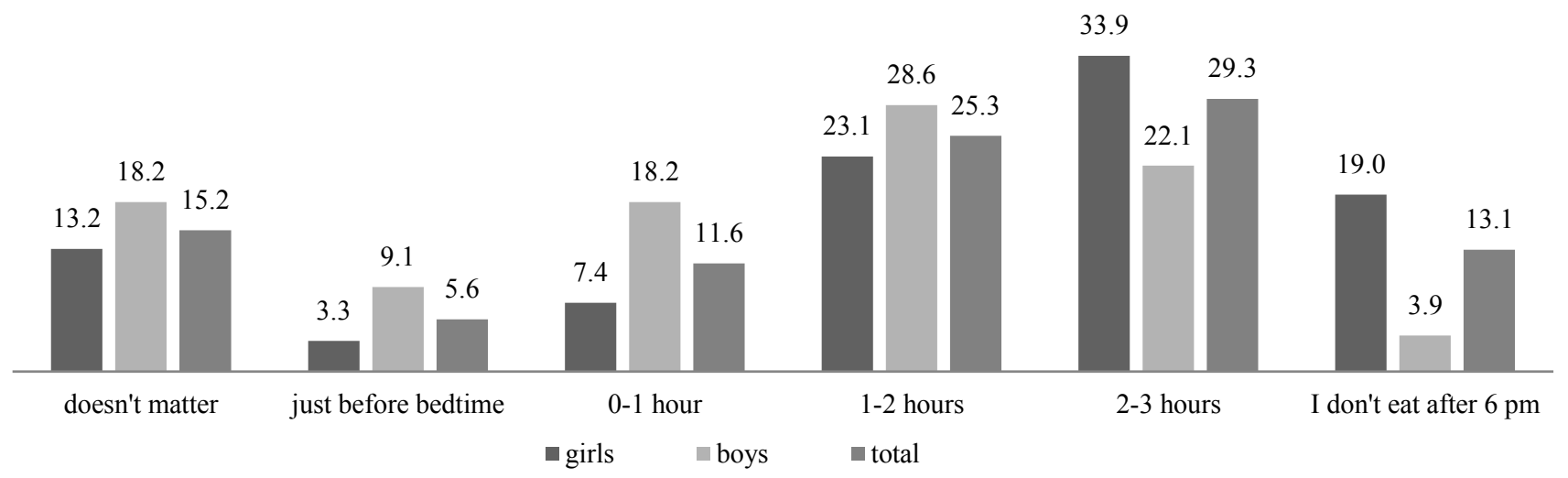

Figure 1. Time of food consumption before sleep [in \%]

It might be speculated that over the years the number of adolescents that are snacking between meals is increasing. Most favorable snacks chosen by girls are fruits, fruit-vegetable juice, yogurts and vegetables. Boys preferred fruit-vegetable juice, fruits, yogurts and white bread (Table 4). Self-assessed dietary knowledge was claimed as "very good" by $19.5 \%$ of boys and $12.4 \%$ girls. The difference is much more significant in terms of "good" statement: boys $45.5 \%$ where in girls just $34.7 \%$. When it comes to self-assessing their knowledge as "good enough", the meaningful difference was noticed (even 20.6\%) between boys (27.3\%) and girls (47.9\%).

Similar situation existed in the dietary selfevaluation. Female adolescents were characterized by a cautious approach towards self-assessment of their nutritional knowledge as "good" or "very good" (Figure 2). Girls assessed it as "very good" only in 5.0\%, whilst boys in $14.3 \%$. Comparable percentage of girls and boys (respectively $44.6 \%$ and $41.6 \%$ ) described their nutrition as "good". At the same time $5.8 \%$ girls and $5.2 \%$ boys, that assessed their nutritional knowledge as "good" and "very good", were snacking "often". The views on a nutritional knowledge $(\mathrm{p}=0.059)$ and dietary self-assessment were not influenced by gender ( $\mathrm{p}=0.173)$. Respondents $(36.7 \%)$ that had been examined by Czarnecka-Skubina and Namyst in 2008 stated that their nutrition was correct (regardless of gender) [6]. This information suggests that nowadays, adolescents have higher opinions of their own diet. 
Table 4. The average intake frequency of snacking and food choice based on gender

\begin{tabular}{|c|c|c|c|c|}
\hline \multirow[b]{2}{*}{ Product } & \multicolumn{4}{|c|}{ Sex } \\
\hline & $\begin{array}{c}\text { All } \\
\mathrm{X} \pm \mathrm{SD}\end{array}$ & $\begin{array}{c}\text { Female } \\
\mathrm{X} \pm \mathrm{SD}\end{array}$ & $\begin{array}{c}\text { Male } \\
\mathrm{X}_{\text {sr }} \pm \mathrm{SD}\end{array}$ & $\begin{array}{l}\text { Statistical } \\
\text { significance } \\
(\mathrm{p}-\mathrm{value})\end{array}$ \\
\hline \multicolumn{5}{|c|}{ Group 1} \\
\hline Whole grain bread & $2.16 \pm 1.19$ & $2.24 \pm 1.13$ & $2.04 \pm 1.13$ & NS \\
\hline White bread & $2.32 \pm 1.17$ & $2.23 \pm 1.13$ & $2.44 \pm 1.23$ & NS \\
\hline Grains, rice & $1.74 \pm 0.99$ & $1.76 \pm 1.02$ & $1.73 \pm 0.95$ & NS \\
\hline \multicolumn{5}{|c|}{ Group 2} \\
\hline Vegetables & $2.38 \pm 1.15$ & $2.46 \pm 1.10$ & $2.26 \pm 1.21$ & NS \\
\hline Fruits & $3.07 \pm 0.97$ & $3.20 \pm 0.88$ & $2.87 \pm 1.07$ & NS \\
\hline \multicolumn{5}{|c|}{ Group 3} \\
\hline Milk and diary products & $2.38 \pm 1.16$ & $2.43 \pm 1.20$ & $2.43 \pm 1.11$ & NS \\
\hline Eggs & $1.61 \pm 0.84$ & $1.52 \pm 0.78$ & $1.75 \pm 0.91$ & NS \\
\hline Yoghurts & $2.56 \pm 1.15$ & $2.60 \pm 1.16$ & $2.49 \pm 1.13$ & NS \\
\hline Cheese & $2.23 \pm 1.17$ & $2.15 \pm 1.11$ & $2.38 \pm 1.24$ & NS \\
\hline \multicolumn{5}{|c|}{ Group 4} \\
\hline Meat products & $2.06 \pm 1.16$ & $2.03 \pm 1.14$ & $2.12 \pm 1.18$ & NS \\
\hline \multicolumn{5}{|c|}{ Group 5} \\
\hline Cookies & $2.19 \pm 1.09$ & $2.09 \pm 1.04$ & $2.35 \pm 1.16$ & NS \\
\hline Nuts, dried fruits & $1.90 \pm 1.05$ & $1.93 \pm 1.09$ & $1.86 \pm 0.97$ & NS \\
\hline Crisps, fries & $1.82 \pm 1.01$ & $1.76 \pm 1.00$ & $1.91 \pm 1.04$ & NS \\
\hline Ice-cream & $1.54 \pm 0.87$ & $1.37 \pm 0.73$ & $1.80 \pm 0.99$ & $\mathrm{SS}(\mathrm{p}=0.014)^{* *}$ \\
\hline Fast-food/hamburgers, hot-dog & $1.43 \pm 0.82$ & $1.28 \pm 0.68$ & $1.66 \pm 0.95$ & $\mathrm{SS}(\mathrm{p}=0.001)$ \\
\hline Soda, Cola-like drinks & $1.76 \pm 1.05$ & $1.56 \pm 0.93$ & $2.05 \pm 1.17$ & $\mathrm{SS}(\mathrm{p}=0.005)$ \\
\hline Diet sodas & $1.43 \pm 0.87$ & $1.31 \pm 0.72$ & $1.62 \pm 1.03$ & $\mathrm{SS}$ \\
\hline
\end{tabular}

$\mathrm{X}$ - mean, $\mathrm{SD}$ - standard deviation

Scale of answer: „every day or several times a week” score $=4$, , few times a week” score $=3$, „once a week” score $=2$, „lees than once a week" score $=1$.

NS - statistically non-significant, SS statistically significant ( $p$-value in $C h i^{2}$ test)

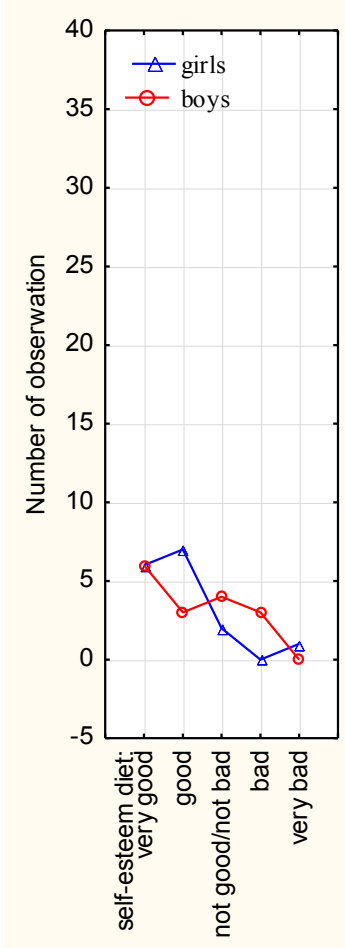

your ow $n$ know ledge on nutrition: very w ell

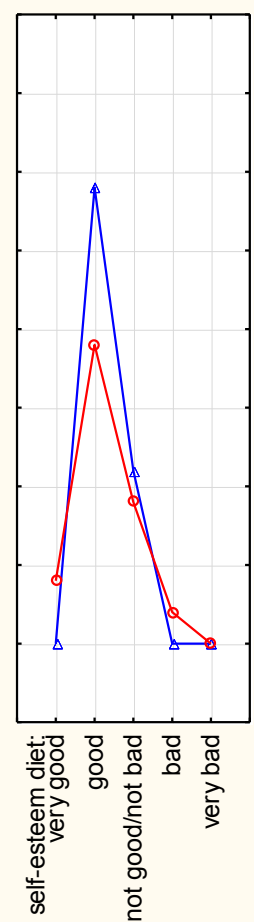

your ow n know ledge on nutrition: good
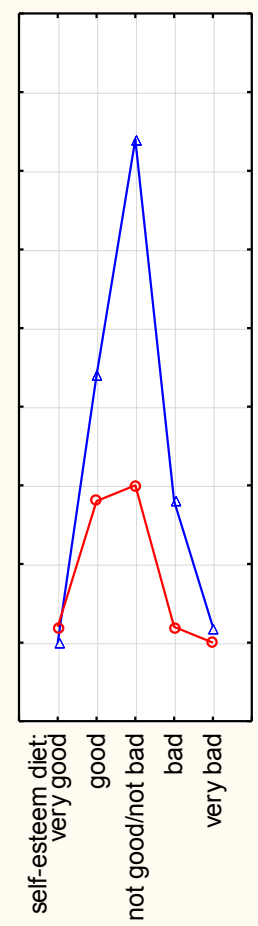

your ow $n$ know ledge on nutrition: satisfactory
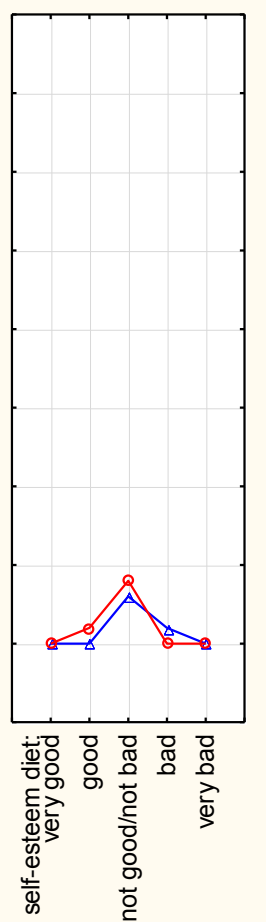

your ow $n$ know ledge on nutrition: insufficient

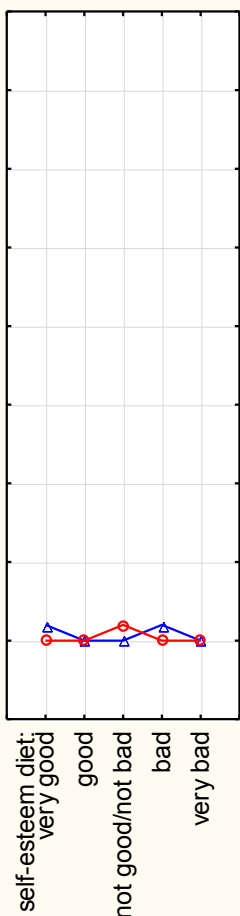

your ow $n$ know ledge on nutrition: I have no know ledge

Figure 2. Self-assessment of eating habits and nutritional knowledge correlated with gender among adolescents 
Being on a special regimen becomes more and more trendy among girls as well as boys [6, 15]. Obviously it doesn't refer to diet required as a part of therapeutic process for example non-gluten diet in celiac disease. Youthful motives are totally different. Female respondents modified their nutrition mostly to reduce body mass, wherein male ones altered their diets to match their physical activity together with a need to build muscle mass. The question about being on a diet was answered in affirmative by $31.4 \%$ girls and $22.1 \%$ boys. Comforting might be fact, that $68.6 \%$ girls and $77.9 \%$ boys did not experiment with alternative diets on themselves. In years 2004-2006 Piórecka at al. [19] showed that only $8.1 \%$ of boys were modifying their nutrition, where in the study (2012-2013) it was $22.1 \%$. Increase of male participation in going on a diet had been observed over the years.

Promoted by mass media "westernization" which is bringing in and accepting western patterns, in this case skinny silhouette, as attractive has its consequences. Many young men and women in a desire to look the same as models try restrictive diets, which with time, alongside with certain psychological predispositions may lead to development of anorexia nervosa [20]. This phenomenon occurs among young women whose career depends on a maintenance of low body mass $[4,29]$.
Respondents listed various types of diets they already had tried or used: "starvation diet", "protein diet", "1000 kcal", "fruit diet", "low-calories diet", "non-gluten diet", "Diet for Young Athletes", "lowcarbs diet", "high-protein diet", "self-restricting diet", "Dr Dukan's diet", "reducing sweets intake", "pescetarianism", "low-fat diet", "muscle mass building diet", "high-calories diet", "apple vinegar", "switching white bread for a whole-grains one", "lots of fruits and non-carb water", "eating organic foods", "vegetables and fruits". Only in a small percentage general practitioners $(5.4 \%)$, dietitians $(3.6 \%)$ or even personal trainers were used as a source of information about healthy diets. Unfortunately the main source was the Internet (36.0\%) and also "own mind" which usually meant mixture of own thinking based on suggestions from the family, friends, colleagues, youtube, online forums for bodybuilders and athletes, magazines and books. This shows glaring lack of meaning of the professionals for adolescents. Those young people do not have an individual approach for own body, simply mixing all the information they get from the society.

In one of the eastern counties of Poland Szczerbiński and Karczewski [23] in 2005-2006 observed that diets were conducted by $23.11 \%$ of all adolescents, which was $37.53 \%$ of girls and only $6.27 \%$ were boys (difference statistically significant).

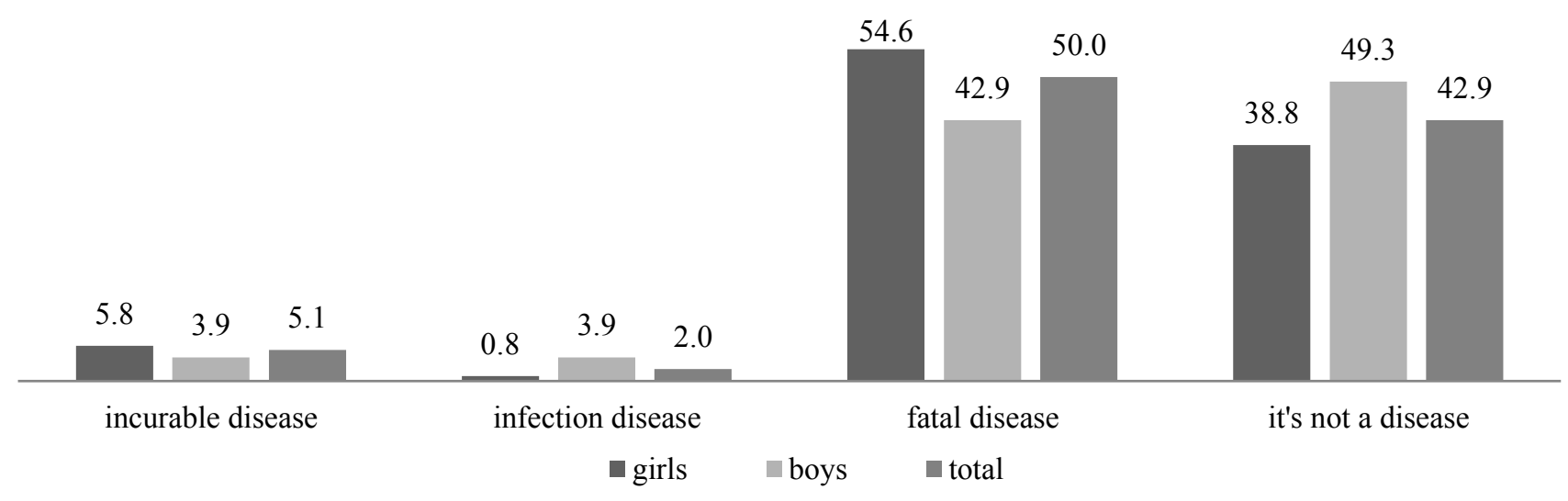

Figure 3. Students' perception of obesity as a disease [in \%]

Points of view on obesity made by adolescents showed that more than half of a female respondents $(54.6 \%)$ and $42.9 \%$ male ones perceived obesity as a morbid disease (Figure 3). Differences in answers given by girls and boys were not statistically significant. Large percentage of girls (38.8\%) and boys $(49.4 \%)$ claimed that obesity is not a disease, simultaneously $14.1 \%$ of girls from that group selfassessed their nutritional knowledge as "good", and $5.0 \%$ as "very good". Among "obesity as a disease" skeptical boys $20.8 \%$ self-assessed their knowledge as "good" and $11.7 \%$ as "very good". Study showed that adolescents still had shortcomings in a subject of proper nutrition, which can predispose them to suffer from non-communicable chronic diseases in the future.

\section{CONCLUSIONS}

1. Boys statistically significantly more frequently consumed dinner $(\mathrm{p}=0.033)$ and supper $(\mathrm{p}=0.028)$. Nutrition among adolescents was characterized by lack of regularity in meal consumption $(41.6 \%$ omitted breakfasts) and too frequent snacking. Boys were consuming statistically significantly more milk, eggs, red meat, poultry and white bread in comparison to girls. Suppers were avoided by 
three times more girls than boys. That can be a direct result of lack of hunger feeling because of excess snacking during the day.

2. Girls (31.4\%) statistically significantly more often decided on a dietary regimen than boys $(22.1 \%)$. It may be due to the need of young females to obtain and sustain skinny figure. This behavior together with lack of proper nutrition education may lead to eating disorders development.

3. Adolescents had insufficient nutrition knowledge accompanied with little consciousness in a danger of an obesity risk. Gender was not influencing dietary self-assessment nor nutritional knowledge. This alarms to initiate conducting special education programs to build the awareness of healthy eating habits.

4. Demonstrated outcomes suggests the need of correction of nutritional knowledge not only among students but also their parents or legal guardians. It should be done with registered dietitians assistance.

\section{Conflict of interest}

The authors declare no conflict of interest.

\section{REFERENCES}

1. Alavil M., Eftekhari M., Noot R., RafinajadJ., Chinekesh A.: Dietary Habits Among Adolescents Girls And Their Association With Parental Educational Levels. Global Journal of Health Science 2013;5(5):201-206. http:// doi: 10.5539/gjhs.v5n5p202.

2. Azizi M., Aghaee N., Ebrahimi M., Ranjbar K.: Nutrition knowledge, the attitude and practices of college students. Physical Education and Sport 2011;9(3):349357.

3. Babicz-Zielińska E., Nazarewicz R., Schlegel-Zawadzka M.: Own body perception as resulting in possible eating disorders among adolescent girls. Żyw Czł Metab 2002; 29(Supl).:366-370 (in Polish).

4. Bartkowicz J.: Analysis Of Selected Nutrition Behaviors And Attitudes Of Sport Mastery School Students. Preliminary Study. Zeszyty Naukowe Akademii Morskiej w Gdyni 2014;86:99-109 (in Polish).

5. Bojar I., Wojtyła A., Biliński P.: Ewaluacja programu edukacyjnego „Trzymaj formę” cz. I. - Odżywianie a zdrowie młodzieży. Warszawa 2010; 5 (in Polish).

6. Czarniecka-Skubina E., Namyst I.: Some Selected Elements of Nutritional Behaviours of Secondary School Children. Żywność Technologia Jakość 2008;6(61):129-143 (in Polish).

7. Fraczek B.: Nutrition manner of teenagers from last class of the secondary school. Żyw Czł Metab 2003;30,1/2:86-92 (in Polish).

8. Gacek M.: Dietary habits and locus of control assessed in middle school from the Malopolska region of Poland. Rocz Państw Zakł Hig 2013;64(2):129-143.
9. Gajda $R$, Jeżewska-Zychowicz M.: Nutritional behaviours of adolescents living in the Świętokrzyskie voivodeship. Probl Hig Epidemiol 2010;91(4):611-617 (in Polish).

10. Gawęcki J. (red).: Żywienie człowieka a zdrowie publiczne. Warszawa, PWN, 2009 (in Polish).

11. Gronowska-Senger A.: Nutrition, Life Style and Health of the Poles. Żyw Czł i Metab 2007;34,1/2:12-21 (in Polish).

12. Hallström L., Vereecken C., Ruiz JR., Patterson E., Gilbert CC., Diaz LE., Gomez-Martinez S., Gonzalez Gross M., Gottrand F., Heqyi A., Lehoux C., Mouratidou T., Widham K., Aström A., Moreno La., Sjöström $M$. Breakfast habits and factors influencing food choices at breakfast in relations to socio-demographic and family factors among European adolescents. Appetite 2011;56:649-657. http://doi: 10.1016/j. appet.2011.02.019.

13. Jarosz M. (red).: Praktyczny Podręcznik Dietetyki. Warszawa, İ̇̇̇, 2010 (in Polish).

14. Jarosz M. (red).: Zasady prawidłowego żywienia dzieci i młodzieży oraz wskazówki dotyczące zdrowego stylu życia. Warszawa, IŻŻ, 2008 (in Polish).

15. Kędra E., Pietras J.: Eating disorders - a sign of our times. Probl Hig Epidemiol 2011;92(3):530-534 (in Polish).

16. Kułaga Z., Różdżýska A., Palczewska I., Grajda A., Gurzkowska B., Napieralska E., Litwin M., group of OLAF. 2010. Standardy Medyczne/ Pediatria T. 7: 690700 (in Polish).

17. Lai Yeung W.T.: Gender Perspectives on Adolescents Eating Behaviors: A Study on the Eating Attitudes and Behaviors of Junior Secondary Students in Hong Kong. Journal of Nutrition Education and Behavior 2010;42(4):250-258. http://doi: 10.1016/j. jneb.2009.05.008.

18. Pederson TP., Meilstrup C., Holstein BE., Rasmussen $M .:$ Fruit and vegetables is associated with frequency of breakfast, lunch and evening meal: cross-sectional study of 11-, 13-, and 15-years olds. Int J of Behav Nutr Phys Act. 2012; 9:1-10. http://doi: 10.1186/1479-5868-9-9

19. Piórecka B., Jagielski P., Wójcik K.., Zwirska J., Schlegel-Zawadzka M.: Eating habits of adolescents in Malopolska Żyw Czł i Metab 2007;XXXIV,1/2:620-628 (in Polish).

20. Ponczek D.. Olszowy I.: Styl życia młodzieży i jego wpływ na zdrowie. Probl Hig Epidemiol 2012;93(2):260-268 (in Polish).

21. Sochacka-Tatara E., Stypuła A.: Zaburzenia odżywiania wśród uczniów szkół krakowskich- część ogólnopolskich badań zaburzeń odżywiania wśród młodzieży. Probl Hig Epidemiol 2010; 91(3): 591-595.

22. Stankiewicz M., Pieszko M., Śliwińska S., Małgorzewicz S., Wierucki Ł., Zdrojewski T., Wyrzykowski B., EysiakSzydłowska $W$.: Prevalence of overweight and obesity, and knowledge and health behaviors of children and adolescents small towns and villages-the results of Project 400 Polish cities. Endokryn Otył i Zab Przem Mat 2010;6(2):59-66 (in Polish). 
23. Szczerbiński B., Karczewski J.: Chosen nutritional behaviours health of students attending secondary school in of Sokolski district. Żyw Czł Metab 2007;34:878-884 (in Polish).

24. Szczerbiński R., Karczewski J., Siemienkowicz J.: Selected Nourishment Habits Depending On Physical Activity Of 14-16 Year-Old Teenagers In The NorthEastern Poland On The Example Of Sokolski District. Rocz Panstw Zakl Hig 201;61(1):83-86 (in Polish).

25. Veltsista A., Laitinen J., Sovio U., Roma E., Järvelin MR., Bakoula Ch.: Relationship between Eating Behavior, Breakfast Consumption, and Obesity Among Finnish and Greek Adolescents. J Nutr Educ. Behav. 2010; 42(6): 417-421. http://doi: 10.1016/j.jneb.2009.12.004.
26. Wadołowska L.: Nutritional health hazards base in Poland. Olsztyn, UWM, 2010.

27. Wierzbicka E., Roszkowski W.: Analysis of food intake, including fast-food meals, by a group of adolescents. Brmatol Chem Toksykol 2005; supl:561-566 (in Polish).

28. Wołowski T., Jankowska M.: Lifestyle of secondary school students-prevelance of chosen health factors. Part I. Nutritional habits. Probl Hig Epidemiol 2007;88(1):64-68 (in Polish).

29. Zuława G., Pilch $W$.: The estimation of nutrition habits of Ballet School students in Krakow. Rocz Panstw Zakl Hig 2012;63(1):106-110 (in Polish).

Received: 30.12 .2017

Accepted 28.08.2018

This article is available in Open Access model and licensed under a Creative Commons Attribution-Non Commercial 3.0.Poland License (CC-BY-NC) available at: http://creativecommons.org/licenses/by-nc/3.0/pl/deed.en 